Revista Eletrônica de Direito Processual - REDP. Volume 15. Janeiro a Junho de 2015

Periódico Semestral da Pós-Graduação Stricto Sensu em Direito Processual da UERJ.

Patrono: José Carlos Barbosa Moreira. www.redp.com.br ISSN 1982-7636 PP 240-267

\title{
A COOPERAÇÃO NO NOVO CÓDIGO DE PROCESSO CIVIL: DESAFIOS \\ CONCRETOS PARA SUA IMPLEMENTAÇÃO
}

\section{COOPERATION IN THE NEW CODE OF CIVIL PROCEDURE: CONCRETE CHALLENGES FOR ITS IMPLEMENTATION}

Humberto Dalla Bernardina de Pinho Professor Associado na UERJ. Promotor de Justiça no Rio de Janeiro/RJ. humbertodalla@gmail.com

Tatiana Machado Alves Mestranda em Direito Processual na UERJ. Advogada no Rio de Janeiro.

RESUMO: O texto trata da cooperação enquanto padrão de conduta das partes no processo compatível com a ideia de processo participativo e democrático. São analisadas questões já enfrentadas pela jurisprudência norte-americana, bem como são traçados alguns parâmetros a serem utilizados pelo direito brasileiro a partir das questões práticas e teóricas que devem surgir com a vigência do novo Código de Processo Civil.

PALAVRAS-CHAVE: Cooperação; novo; Código; Processo civil; desafios.

\begin{abstract}
The text deals with cooperation as a standard of conduct of the parties compatible with the idea of participatory and democratic process. It analyzes issues already faced by North american jurisprudence. Besides, the text points out some parameters to be used by Brazilian law from practical and theoretical issues that should arise with the approval of the new Civil Procedure Code.
\end{abstract}

KEYWORDS: cooperation; new; code; Civil procedure; challenges. 
Revista Eletrônica de Direito Processual - REDP. Volume 15. Janeiro a Junho de 2015

Periódico Semestral da Pós-Graduação Stricto Sensu em Direito Processual da UERJ.

Patrono: José Carlos Barbosa Moreira. www.redp.com.br ISSN 1982-7636 PP 240-267

SUMÁRIO: 1. Introdução. 2. A cooperação no direito norte-americano. 3. A cooperação no novo Código de Processo Civil Brasileiro. 4. Os desafios para a implementação da cooperação no processo. 5. Conclusões. 6. Referências bibliográficas.

\section{Introdução}

Um dos problemas do sistema jurídico brasileiro que o novo Código de Processo Civil (Lei $n^{\circ}$ 13.105), publicado no Diário Oficial da União em 17 de março de 2015, se propõe a atenuar - uma vez que resolver parece ser uma pretensão muito ambiciosa - é a morosidade do Poder Judiciário, que coloca em xeque a eficácia da prestação jurisdicional e a operosidade da Justiça.

Em carta endereçada ao Senador José Sarney, Presidente do Senado, por ocasião da apresentação do Anteprojeto do Código em 2010, o Ministro Luiz Fux já manifestava a preocupação com este problema, ressaltando o objetivo da Comissão de Juristas por ele presidida de "resgatar a crença no judiciário e tornar realidade a promessa constitucional de uma justiça pronta e célere”.

Para tanto, os desafios não são poucos - e nem fáceis. Um elevado número de ações que cresce mais a cada dia ${ }^{1}$, uma grande quantidade de mecanismos legítimos que nas mãos erradas podem ser usados para atravancar o processo, e toda uma cultura nacional que gira em torno da litigiosidade.

Algumas medidas vêm sendo adotadas para tentar diminuir esta carga que assoberba o Poder Judiciário. É o caso das metas do CNJ, dos mutirões de conciliação e dos projetos de Lei que buscam uma reestruturação do processo civil e dos mecanismos alternativos de solução de conflitos. Nesse sentido, a arbitragem, a conciliação e a mediação aparecem como opções atraentes para a solução de conflitos interpessoais de forma mais eficaz e célere, contribuindo para a redução na quantidade de processos judiciais.

Não obstante, persiste a questão sobre o que fazer quando não há condição de as partes entrarem em um acordo - seja pela própria natureza do conflito (i.e. referente a

\footnotetext{
${ }^{1}$ Os números mais recentes do Conselho Nacional de Justiça, contidos no Relatório "Justiça em Números 2014" (http://www.cnj.jus.br/programas-de-a-a-z/eficiencia-modernizacao-e-transparencia/pj-justica-emnumeros/relatorios), com relação ao ano de 2013, são alarmantes. Eles indicam o aumento progressivo do número de processos, cerca de $3,4 \%$ por ano, resultado do ingresso de 28,3 milhões de novos casos em 2013 e de um número de processos baixados inferior ao de casos novos. Tramitam, atualmente, 95,14 milhões de processos na Justiça brasileira - um número impressionante se considerarmos que a população brasileira em Julho de 2014 era de 202,7 milhões de habitantes.
} 
Revista Eletrônica de Direito Processual - REDP. Volume 15. Janeiro a Junho de 2015 Periódico Semestral da Pós-Graduação Stricto Sensu em Direito Processual da UERJ. Patrono: José Carlos Barbosa Moreira. www.redp.com.br ISSN 1982-7636 PP 240-267 direitos indisponíveis), seja por questões pessoais (i.e. ausência de concordância entre as partes).

Nesses casos, por mais bem estruturado que seja o processo civil, por mais bem aparelhado que seja o Poder Judiciário, por mais dedicados que sejam os Juízes e servidores, o processo nunca andará para frente se existirem pessoas dispostas a atrasálo - através de mecanismos legítimos ou não. Quando a única solução é o litígio, será que é necessário que as partes entrem em guerra umas com as outras, ou seria possível estabelecer uma comunidade de trabalho pacífica entre elas e com o juiz?

Nessa dimensão, o novo Código de Processo Civil, na esteira do que vem sendo realizado em outras jurisdições ${ }^{2}$, traz diversos dispositivos que representam uma tentativa do legislador infraconstitucional de incrementar uma atuação mais cooperativa dos sujeitos processuais, com a finalidade de assegurar a efetividade do próprio processo e, com isso, aprimorar o acesso à Justiça. Neste sentido, um desses dispositivos é o art. $6^{\circ}$ do Projeto de Lei recém-aprovado, que traz a previsão de uma cláusula geral de cooperação no processo civil ${ }^{3}$.

Ainda é cedo para dizer como esse dispositivo será encarado pela comunidade jurídica brasileira. Alguns questionamentos já vêm sendo suscitados por doutrina abalizada: quais os efeitos da inobservância desta norma? Como o juiz poderia assegurar o seu cumprimento? Não seria utópico esperar que as partes cooperem "entre si'?

Não há dúvidas de que a implementação concreta de uma norma dotada de um caráter extremamente abstrato e conteúdo aberto apresenta inúmeras dificuldades. Estas não podem, contudo, desanimar aqueles interessados em um processo mais célere justo de buscarem soluções e respostas. Assim, fomos buscar no ordenamento jurídico norteamericano uma luz que ajude a doutrina nacional a guiar esse caminho.

\section{A cooperação no Direito norte-americano}

O problema da morosidade da Justiça, do assoberbamento do Poder Judiciário, e das condutas beligerantes das partes não é exclusividade do Brasil. Nos Estados Unidos,

\footnotetext{
${ }^{2}$ Conforme será demonstrado mais adiante, países como Portugal, Alemanha e Estados Unidos têm incorporado em seus diplomas legais previsões genéricas de deveres de cooperação e de boa-fé dos sujeitos da relação jurídica processual, e previsões específicas que visam concretizar o objetivo de um processo mais fraterno e eficiente.

${ }^{3}$ Art. $6^{0}$ : "Todos os sujeitos do processo devem cooperar entre si para que se obtenha, em tempo razoável, decisão de mérito justa e efetiva".
} 
Revista Eletrônica de Direito Processual - REDP. Volume 15. Janeiro a Junho de 2015 Periódico Semestral da Pós-Graduação Stricto Sensu em Direito Processual da UERJ. Patrono: José Carlos Barbosa Moreira. www.redp.com.br ISSN 1982-7636 PP 240-267 por exemplo, havia, em 2012, um total de 96 milhões de casos apenas nas justiças estaduais ${ }^{4}$.

Não obstante o país tenha experimentado uma queda de $9,4 \%$ no número de ações entre 2008 e 2012, provavelmente decorrente da recessão vivida em 2008 e 2009, trata-se de um número inegavelmente alto, especialmente quando somado ao número de processos na justiça federal: em 31 de março de 2014 havia cerca de 1,9 milhão de ações pendentes ${ }^{5}$.

Chama a atenção ainda que, de acordo com pesquisa realizada pelo Bureau of Justice norte-americano, apenas 3,5\% das ações naquele país chegam ao trial, enquanto que a maioria é resolvida por acordos ${ }^{6}$. Além disso, o tempo médio nacional para que uma ação seja julgada em primeira instância é de 27 meses quando houver júri e 21 meses quando não houver.

Embora a situação da justiça norte-americana não pareça ser tão grave quanto a brasileira, há nos Estados Unidos, assim como aqui no Brasil, a preocupação com a necessidade de implementação de medidas que tornem o processo mais célere e menos custoso. Nesse sentido, uma das maiores preocupações no sistema jurídico norteamericano é com a fase probatória, a qual geralmente consome a maior parte do tempo e do dinheiro.

No processo civil norte-americano, a etapa da discovery, consistente na produção de provas pelas partes ${ }^{7}$, envolve muitas vezes disputas desnecessárias, com elevado custo e retardamento da entrega da prestação jurisdicional. Tais disputas são, em diversos casos, geradas pelo interesse de uma das partes em atrasar ou dificultar a resolução do mérito, seja como forma de evitar uma decisão desfavorável, seja para

\footnotetext{
${ }^{4}$ Dado obtido no estudo "Examining the work of state courts: an overview of 2012 State Trial Court caseloads". National Center for State Courts - Courts Statistics Project. Disponível em: http://www.courtstatistics.org/ /media/Microsites/Files/CSP/NCSC_EWSC_WEB_NOV_25_14.ashx. Acesso em 07 jan 2015.

5 Dado obtido em http://www.uscourts.gov/Statistics/FederalJudicialCaseloadStatistics/caseloadstatistics-2014.aspx. Acesso em 07 jan 2015.

${ }^{6}$ Disponível em http://www.bjs.gov/content/pub/pdf/cbjtsc05.pdf. Acesso em 07 jan 2015.

${ }^{7}$ Mary Kay Kane aponta a importância da fase da discovery para o processo civil norte-americano e ressalta o fato de que a sua eficácia depende da sua realização fora do âmbito processual (i.e. entre as partes, com mínima interferência possível do Judiciário): "Even if it does not result in obviating the need for a trial, if properly used, Discovery should aid in producing a crystallized trial. With full revelation of facts between the parties, the trial becomes less of a 'game of wits' and more of a probing into the actual truth of certain facts. This results in a savings for the judicial system, as well as in a fairer and more just trial. (...) The effectiveness of any discovery system depends in great measure on whether it can operate extrajudicially. Otherwise, the amount of time saved at trial is lost in litigation over discovery orders. (...) the only time the parties appear before courts during discovery is when some problem or disagreement arises concerning the valid scope of an inquiry". (in Civil Procedure, $7^{\text {th }}$ edition. West: 2013, p. 137/138).
} 
Revista Eletrônica de Direito Processual - REDP. Volume 15. Janeiro a Junho de 2015 Periódico Semestral da Pós-Graduação Stricto Sensu em Direito Processual da UERJ. Patrono: José Carlos Barbosa Moreira. www.redp.com.br ISSN 1982-7636 PP 240-267

forçar a outra parte a fechar um acordo mediante a ameaça de uma longa e custosa batalha.

Não é preciso muita explicação para demonstrar o prejuízo que isso traz para o sistema judiciário como um todo.

Preocupados com esta situação, em 2008, diversos juristas norte-americanos, reunidos em um grupo de trabalho da Sedona Conference, um instituto norte-americano dedicado a pesquisa e estudo avançado do direito, elaboraram a "Cooperation Proclamation" ${ }^{\prime}$, posteriormente endossada por diversos outros juristas, advogados e juízes.

A “Cooperation Proclamation” busca promover o diálogo, o treinamento dos advogados e dos juízes, e o desenvolvimento de mecanismos práticos que facilitem a cooperação e a colaboração no processo civil, especialmente na etapa da discovery.

A finalidade desta iniciativa é fazer com que o processo volte a se focar na resolução substantiva das disputas legais, ao invés de se perder em meio a discussões desnecessárias que somente servem para entravar o processo e impedir a discussão do mérito 9 .

Conforme bem apontado pela "Cooperation Proclamation”, ao contrário do que poderia parecer à primeira vista, a cooperação não é contrária ao dever do advogado de zelo para com o seu cliente.

Em verdade, ela envolve uma atuação transparente e sincera, a qual se dá não só com relação ao juiz, mas entre as próprias partes e procuradores, no sentido de se comunicarem para identificarem os pontos que realmente reclamam uma decisão judicial e aqueles nos quais as partes, por conta própria, podem chegar a um consenso. Não se pretende obrigar as partes a concordarem sempre, mas a identificarem mais prontamente as verdadeiras questões do processo.

A “Cooperation Proclamation” lembra, ainda, que os advogados, além dos deveres em relação a seus clientes, também exercem um papel de agentes da Corte ("officers of the Court”), o que exige uma atuação sincera e colaborativa com o exercício da jurisdição.

\footnotetext{
8 The Sedona Conference Cooperation Proclamation in The Sedona Conference Journal, volume 10, suplemento, 2009, p. 331. Disponível em: https://thesedonaconference.org/cooperation-proclamation. Acesso em 21 jan 2015.

${ }^{9}$ Op. e Loc. Cit.
} 
Revista Eletrônica de Direito Processual - REDP. Volume 15. Janeiro a Junho de 2015 Periódico Semestral da Pós-Graduação Stricto Sensu em Direito Processual da UERJ. Patrono: José Carlos Barbosa Moreira. www.redp.com.br ISSN 1982-7636 PP 240-267

Aqui poderia ser traçada uma analogia com o Direito brasileiro, no qual o advogado é reconhecido na própria Constituição Federal de 1988 como “indispensável à administração da justiça” (art. 133). Assim, o princípio da cooperação exerce um papel fundamental de delimitação da atuação ética e proba por parte dos advogados, uma vez que eles exercem uma atividade essencial para o desenvolvimento do processo.

O texto reconhece, entretanto, que não é fácil estabelecer uma cultura de cooperação no processo civil. No caso dos advogados mais jovens a dificuldade estaria no domínio das técnicas cooperativas, as quais, a priori, parecem demandar uma maior maturidade emocional e profissional.

Por outro lado, mudar a mentalidade de advogados sêniores, acostumados a “esconderem o jogo" em disputas legais, também é uma tarefa árdua. A situação se complica diante da falta de interesse de alguns advogados em uma atuação cooperativa, o que pode desestimular aqueles que teriam interesse em atuar nestes termos, por medo de saírem prejudicados ${ }^{10}$.

Artur César Souza ${ }^{11}$ lembra que posturas como essas, de cunho meramente individualista, não podem mais ser toleradas no processo contemporâneo.

Nesse sentido, uma outra dificuldade que pode ser experimentada pelos advogados consiste na falta de interesse de seu próprio cliente em atuar cooperativamente, o que pode decorrer de um desconhecimento do significado da cooperação - no que ela consiste de fato quando exercida no âmbito do processo.

Aqui entra o papel do procurador de explicar para o seu cliente - mesmo aquele mais agressivo - que cooperar não é sinônimo de "jogar a toalha". Ninguém espera que uma parte forneça à outra teses jurídicas, ou ajude-a a melhorar sua argumentação, mas sim que as partes atuem em conjunto para buscar uma solução que seja melhor para ambas, na medida em que auxilia na resolução do feito.

Em uma análise mais profunda, o texto "The Case for Cooperation" "12, do mesmo grupo de trabalhos da Sedona Conference, destrincha a cooperação nas Federal

\footnotetext{
${ }^{10}$ Ibid., p. 332.

11 "Portanto, no momento atual do desenvolvimento do processo jurisdicional, não se aceita mais uma postura individualista daqueles que devam participar do processo jurisdicional, pois sendo o fim último do processo a realização da justiça, a colaboração mútua e recíproca deverá ser o norte das condutas praticas na relação jurídica processual”. SOUZA, Artur César. O Princípio da Cooperação no Projeto do Novo Código de Processo Civil, in Revista de Processo, vol. 225, Nov. 2013, São Paulo: Revista dos Tribunais, p. 65.

12 The Sedona Conference Cooperation Proclamation in The Sedona Conference Journal, volume 10, suplemento, 2009, p. 339. Disponível em: https://thesedonaconference.org/cooperation-proclamation. Acesso em 21 jan 2015.
} 
Revista Eletrônica de Direito Processual - REDP. Volume 15. Janeiro a Junho de 2015 Periódico Semestral da Pós-Graduação Stricto Sensu em Direito Processual da UERJ. Patrono: José Carlos Barbosa Moreira. www.redp.com.br ISSN 1982-7636 PP 240-267

Rules of Civil Procedure e nas regras de conduta profissional de advogados, e os

benefícios da cooperação para o processo como um todo.

Para tanto, o texto parte de uma distinção entre dois níveis de cooperação. $\mathrm{O}$ primeiro corresponderia mais propriamente ao que identificamos como boa-fé objetiva, na medida em que se refere ao dever das partes de atuarem com honestidade e boa-fé, evitando práticas abusivas. Nessa perspectiva, as partes não precisam ter uma atuação proativa de atuar conjuntamente, mas elas precisam de boa-fé para tentar resolver os seus problemas, assumindo uma postura defensiva caso não consigam.

Por sua vez, o segundo nível da cooperação corresponde ao princípio da cooperação propriamente dito, ao qual o texto se refere como um "nível de cooperação avançado", no qual as partes devem efetivamente atuar juntas para definir os pontos que devem ser esclarecidos na etapa probatória, discutindo questões como os ônus que serão gerados pela produção de determinada prova e se eles estão de acordo com o teste de proporcionalidade. Nessa dimensão, o princípio da cooperação traz uma evidente vantagem prática para as partes, consistente na economia de tempo e dinheiro com a redução das discussões.

Na doutrina nacional ${ }^{13}$, igualmente já se chamou a atenção para o fato de que a

13 “O princípio de cooperação, porém, não se verifica apenas na etapa de saneamento do processo e na de remoção de eventuais obstáculos à apreciação do mérito. Há outros momentos importantes em que o conteúdo normativo deste princípio encontra-se bem delineado, a saber: (a) as partes e seus procuradores têm o dever de contribuir para a rápida solução da lide, colaborando com o juiz para a identificação das questões de fato e de direito e abstendo-se de provocar incidentes desnecessários e procrastinatórios (art. 8.o do projeto do novo CPC); (b) dever de proceder com boa-fé (art. 80, II, do Projeto do novo (PC); (c) dever de não formularem pretensões, nem alegarem defesa, cientes de que são destituidas de fundamento (art. 80, III, do Projeto do novo CPC); (d) dever de não produzir provas, nem praticar atos inúteis ou desnecessários à declaração ou à defesa do direito (art. 80, IV, do Projeto do novo CPC); (e) dever de cumprir com exatidão as decisões de caráter executivo ou mandamental e não criar embaraços à efetivação de pronunciamentos judiciais, de natureza antecipatória ou final (art. 80, $V$, do Projeto do novo CPC); (f) dever de declinar o endereço, residencial ou profissional, em que receberão intimações, atualizando essa informação sempre que ocorrer qualquer modificação temporária ou definitiva (art. 80, VI, do Projeto do novo CPC); (g) dever de não por resistência injustificada ao andamento do processo (art. 83, IV, do Projeto do novo $C P C$ ); (h) dever de não proceder de modo temerário em qualquer incidente ou ato do processo (art. 83, V, do Projeto do novo CPC); (i) dever de não provocar incidentes manifestamente infundados (art. 83, VI, do Projeto do novo CPC); (j) dever de não interpor recurso com intuito manifestamente protelatório (art. 83, VII, do Projeto do novo CPC); (k) dever do autor adiantar as despesas relativas a atos cuja realização o juiz determinar de oficio ou a requerimento do Ministério Público, quando sua intervenção ocorrer como fiscal da ordem jurídica; (l) dever do advogado ou da parte, quando postular em causa própria, declarar na petição inicial ou na contestação, o endereço em que receberá intimação e comunicar ao juízo qualquer mudança de endereço (art. 103, I e II, do Projeto do novo CPC); (m) dever do autor adotar as providências necessárias para a citação do réu nos dez dias subsequentes ao despacho que a ordenar (art. 209, § 2.o do Projeto do novo CPC); (n) ninguém, muito menos as partes, se eximem do dever de colaborar com o Poder Judiciário para o descobrimento da verdade (art. 364 do Projeto do novo CPC); (o) dever da parte comparecer em juízo, respondendo ao que lhe for perguntado (art. 365, I, do Projeto do novo CPC); ( $p$ ) dever de colaborar com o juízo na realização de inspeção judicial que for considerada necessária (art. 365, II, do 
Revista Eletrônica de Direito Processual - REDP. Volume 15. Janeiro a Junho de 2015 Periódico Semestral da Pós-Graduação Stricto Sensu em Direito Processual da UERJ. Patrono: José Carlos Barbosa Moreira. www.redp.com.br ISSN 1982-7636 PP 240-267

real extensão da cooperação é bem maior do que inicialmente imaginado.

Interessante relembrar, a essa altura, que o objetivo da cooperação não é fazer com que as partes concordem em tudo, mas que ao menos as disputas desnecessárias possam ser resolvidas mediante um consenso entre elas, não havendo porque criar entraves a cada passo para frente que caminha a marcha processual. O objetivo da cooperação, portanto, é limitar a intervenção do Juiz apenas aqueles casos nos quais ela seria absolutamente necessária, permitindo que os Tribunais otimizem o seu próprio trabalho.

A economia tanto de tempo como de dinheiro, por exemplo, é um aspecto que, como visto, também suscita preocupação no Brasil. Assim como nos Estados Unidos, a criação de impasses, de dificuldades, de incidentes meramente protelatórios, e a falta de interesse em colaborar na resolução do litígio, torna o processo no Brasil algo desnecessariamente caro e demorado, em prejuízo à efetividade da prestação jurisdicional.

Muito embora as Federal Rules of Civil Procedure não prevejam expressamente um dever geral de cooperação no direito norte-americano, a doutrina reconhece que há sim um dever implícito na "estrutura e no espírito das regras"14, uma vez que tais regras teriam sido estabelecidas para evitar o uso de táticas e manobras processuais que impedissem ou dificultassem a descoberta da verdade dos fatos.

Haveria, portanto, um reflexo da cooperação nas regras já presentes no Federal Rules of Civil Procedure, a partir das quais seria possível extrair uma necessidade (senão um dever) geral de atuação imbuída de espírito cooperativo no processo civil.

A "Cooperation Proclamation" e os demais textos da Sedona Conference serviram como um pontapé inicial para discussões mais profundas, e para tentativas de aplicação da cooperação nos casos concretos, na maior parte das vezes por iniciativa dos magistrados.

Em artigo sobre o tema, David J. Waxse ${ }^{15}$ questiona, contudo, o por quê da cooperação não ocorrer com a frequência desejada, bem como o que poderia ser feito para reverter esse quadro.

Projeto do novo CPC); (q) dever da parte praticar o ato que lhe for determinado (art. 365, III, do Projeto do novo CPC)"'. SOUZA, Artur César. Op. cit., p. 71.

\footnotetext{
${ }^{14}$ The Sedona Conference Cooperation Proclamation, op. cit., p. 345.

${ }^{15}$ WAXSE, David J. Cooperation - what is it and why do it? XVIII Rich. J.L. \& Tech 8, 2012. Disponível em: http://jolt.richmond.edu/v18i3/article8.pdf. Acesso em 7 jan 2015.
} 
Revista Eletrônica de Direito Processual - REDP. Volume 15. Janeiro a Junho de 2015 Periódico Semestral da Pós-Graduação Stricto Sensu em Direito Processual da UERJ. Patrono: José Carlos Barbosa Moreira. www.redp.com.br ISSN 1982-7636 PP 240-267

Boa parte desta "culpa" recai, segundo Waxse, sobre os próprios advogados de contencioso, os quais, em sua maioria, possuiriam uma natureza beligerante, tendendo mais para o conflito do que para a cooperação. Além disso, ele aponta uma concepção errada sobre o conceito de cooperação, visto como um sinal de fraqueza, e sobre a sua compatibilidade com o dever de advocacia zelosa.

Dessa forma, muitos advogados optariam por não cooperar por entender que isso seria mal visto por seus clientes, na medida em que estes prefeririam uma atuação combativa por parte dos seus procuradores.

Assim como Waxse, Richard Marcus ${ }^{16}$ reproduz o entendimento de que a razão para a falta de cooperação e para a supervalorização da disputa decorre da pressão exercida pelos clientes sobre seus advogados, os quais deixaram de ser vistos como conselheiros e guias, predominando a mentalidade de que o advogado deve fazer o que o cliente quer - e o que ele quer é um advogado agressivo, e não um "cooperador".

A agressividade da advocacia norte-americana levou inclusive a doutrina a adotar o termo Rambo litigation para se referir às disputas dominadas por advogados que empregam quaisquer táticas necessárias para a vitória, não importando o quão repugnante elas sejam.

Seja qual for a causa, muito se discute no direito norte-americano sobre a melhor forma de promover a cooperação no processo civil. Se por um lado Richard Marcus questiona sobre se a cooperação deveria ou poderia tornar-se obrigatória, o que inclui a questão atinente às possíveis consequências da inobservância do dever de cooperação, tanto Marcus como Waxse reconhecem que a demanda por um comportamento que pode ser tido como cooperativo está presente em diversas normas esparsas das Federal Rules of Civil Procedure.

Os autores divergem, todavia, sobre a interpretação do escopo da Regra 1. Enquanto Marcus afirma que esta não traz uma previsão de cooperação, não abordando sequer a possibilidade de extração de um comando implícito, Waxse entende que a redação atual deste dispositivo legal já traz intrinsicamente uma orientação para cooperação, na medida em que estabelece que o objetivo do processo é a justa, célere e econômica composição da lide, e esta só pode ser alcançada através de uma atuação cooperativa das partes e do juiz.

16 MARCUS, Richard. Cooperation and Litigation: Thoughts on the American Experience, p. 1. Disponível em: < http://papers.ssrn.com/sol3/papers.cfm?abstract_id=2330634>. Acesso em 7 jan 2015. 
Revista Eletrônica de Direito Processual - REDP. Volume 15. Janeiro a Junho de 2015 Periódico Semestral da Pós-Graduação Stricto Sensu em Direito Processual da UERJ. Patrono: José Carlos Barbosa Moreira. www.redp.com.br ISSN 1982-7636 PP 240-267

Assim, caberia aos sujeitos do processo observar as demais regras processuais que implicam na cooperação como resultado da sua implementação.

Dentre essas regras, podemos citar, por exemplo, a Regra 26 (g) (3) que prevê uma sanção que pode ser aplicada pelo juiz de ofício ou a pedido de uma das partes quando a outra parte formula requerimentos de produção de prova que não estejam de acordo com as normas processuais, ou que sejam protelatórios ou desnecessários, ou ainda que não sejam razoáveis, tudo à luz das necessidades do caso e do bem que se busca proteger.

Outro dispositivo interessante do direito norte-americano é o parágrafo 1927 do título 27 do Código de Leis dos Estados Unidos (U.S. Code), que prevê a responsabilidade do advogado pelos custos excessivos incorridos durante $\mathrm{o}$ procedimento de forma abusiva ou desarrazoada. Tal dispositivo pode ser lido, ainda que indiretamente, como um incentivo à cooperação, na medida em que fomenta a atuação responsável dos procuradores, sob pena de serem responsabilizados pessoalmente.

Dessa forma, ainda que não haja, hoje, uma regra expressa prevendo um dever geral de cooperação no direito norte-americano, as regras já existentes proporcionam um terreno fértil para o desenvolvimento de uma atuação processual cooperativa, através de orientações para os advogados (e para as partes) trilharem o caminho da cooperação e de mecanismos para o juiz assegurar que eles não desviem deste caminho na busca de seus objetivos.

Não obstante, em busca do fortalecimento da cooperação, a Federal Judicial Conference Standing Committee on Rules of Practice and Procedure, entidade responsável, dentre outras funções, pelas alterações ao Federal Rules of Civil Procedure, promoveu, em 2010, uma conferência sobre processo civil (Conference on Civil Litigation), na Universidade de Duke, nos Estados Unidos.

Durante esta conferência discutiu-se a questão dos custos do processo civil, principalmente aqueles derivados da etapa do discovery, e as medidas que poderiam ser adotadas para solucionar, ou ao menos amenizar, este problema.

De acordo com David J. Waxse ${ }^{17}$, muito embora tenham sido discutidas propostas de alterações às Federal Rules of Civil Procedure, não houve consenso quanto alterações específicas que poderiam ser feitas. A conclusão a que os

\footnotetext{
${ }^{17}$ WAXSE, David. J. Op. cit., p. 2.
} 
Revista Eletrônica de Direito Processual - REDP. Volume 15. Janeiro a Junho de 2015 Periódico Semestral da Pós-Graduação Stricto Sensu em Direito Processual da UERJ. Patrono: José Carlos Barbosa Moreira. www.redp.com.br ISSN 1982-7636 PP 240-267

participantes do evento chegaram foi a de que, embora o processo civil norte-americano funcione razoavelmente bem, dispensando, portanto, maiores reestruturações, ele ainda é um procedimento caro e demorado, de modo que o incentivo à cooperação, especialmente durante a etapa probatória, é uma medida a ser tomada.

A partir das conclusões elaboradas durante a conferência de 2010, o comitê da Federal Judicial Conference deu início a discussões mais concretas sobre propostas de alterações às Federal Rules of Civil Procedure, as quais foram aprovadas em Setembro de 2014 pela Judicial Conference e enviadas para a revisão da Suprema Corte norteamericana, etapa necessária antes de serem examinadas no Congresso daquele país.

A proposta de alteração mais significativa, pelo menos no que tange à cooperação, é a nova redação da regra 1 das Federal Rules of Civil Procedure. Hoje este dispositivo estabelece que as regras processuais "should be construed and administered to secure the just, speedy, and inexpensive determination of every action and proceeding" (devem ser construídas e administradas para assegurar a justa, célere e econômica composição da lide), mas, de acordo com a emenda proposta, ele passaria a estabelecer que as regras "should be construed, administered, and employed by the court and the parties to secure the just, speedy, and inexpensive determination of every action and proceeding" (devem ser construídas, administradas, e empregadas pela Corte e pelas partes para assegurar a justa, célere e econômica composição da lide).

Uma mudança aparentemente pequena, mas com potencial de impacto significativo sobre o processo civil norte-americano como um todo.

O objetivo declarado desta alteração é deixar claro que as partes, assim como as Cortes, têm a responsabilidade de alcançar a justa, célere e econômica resolução de qualquer ação, o que clama por uma advocacia eficiente, que faz um uso cooperativo e proporcional do procedimento à disposição.

Assim, mais do que um direito, as partes têm um verdadeiro dever para com a administração responsável da Justiça de atuar dentro de um parâmetro de conduta que permita a prolação de decisões justas, em tempo razoável e com economia de custos.

Um ponto interessante é que, após ter sido submetida a consulta pública, em maio de 2014, foram levantados questionamentos sobre esta proposta de alteração à regra 1 , sob o argumento de que a nova redação poderia ser utilizada como fundamento para pedidos de aplicação de sanções em casos de violações ao dever de cooperação. 
Revista Eletrônica de Direito Processual - REDP. Volume 15. Janeiro a Junho de 2015 Periódico Semestral da Pós-Graduação Stricto Sensu em Direito Processual da UERJ. Patrono: José Carlos Barbosa Moreira. www.redp.com.br ISSN 1982-7636 PP 240-267

$\mathrm{O}$ comitê encarregado da elaboração das emendas prontamente esclareceu que

"This amendment does not create a new or independent source of sanctions. Neither does it abridge the scope of any other of these rules" (esta emenda não cria uma nova ou independente fonte de sanções. Tampouco limita o escopo de nenhuma outra regra), pondo fim a qualquer eventual especulação sobre o tema.

A questão sobre as consequências da inobservância do dever de cooperação suscita dúvidas e discussões nos ordenamentos jurídicos nos quais este dever é uma realidade (ou está em vias de se tornar).

Com efeito, soa arriscado afirmar que de um dever geral de cooperação possam surgir sanções punitivas não previstas na Lei para a parte que não cooperar, especialmente tendo em vista a ausência de uma definição precisa sobre quais tipos de comportamentos podem ser considerados cooperativos e quais são indicativos de uma recusa da parte (e/ou de seu advogado) em cooperar.

O risco é grande de que isso dê origem a arbítrios por parte do Poder Judiciário ou de que direitos e garantias processuais sejam indevidamente limitados ${ }^{18}$.

Por outro lado, a ausência de qualquer consequência para a observância ou inobservância da cooperação também é prejudicial, na medida em que desestimula as partes e seus procuradores a cooperarem. Afinal, ao menos à primeira vista parece que as vantagens que a cooperação traz para o processo não são suficientes para incentivar uma atuação mais cooperativa e menos beligerante.

Assim, além da educação dos sujeitos do processo quanto à importância e à necessidade de cooperação no processo civil, de forma que a longo prazo esse comportamento se torne inerente a todos aqueles que se envolvem em um litígio,

\footnotetext{
${ }^{18}$ Em sentido contrário, pugnando pela necessidade de previsão de expressa de sanção, encontramos na doutrina patria o excelente texto de Marcio Farias: "A despeito de toda essa influência - e aí reside o cerne de nossas considerações -, tanto o Projeto, como o texto aprovado no Senado Federal e, ainda, a última versão do Relatório deixaram de consagrar uma sanção expressa para o caso de descumprimento do dever de colaboração, lacuna essa que, no dia a dia forense, pode significar um descrédito inaceitável à retrocitada norma fundamental. Isso porque, tratando-se de regra sem sanção específica, sua aplicabilidade prática, quer sob o aspecto preventivo, quer sob o aspecto repressivo, certamente se mostrará capenga, porquanto servirá, no máximo, como um dever moral que, se descumprido, dificilmente acarretará prejuizos sensíveis ao litigante ímprobo. Noutro giro: aquele que, em evidente desvio de finalidade, busca se valer do processo para obstar/adiar a satisfação do direito da parte contrária ou, ainda, aquele que, aproveitando-se de seu bom direito, extrapola os limites da tutela jurisdicional, em manifesto abuso, não se verá desincentivado a assim proceder se não houver - como não há - uma previsão de sanção especifica para o desrespeito à colaboração”. FARIAS, Marcio. A lealdade processual, o Projeto de novo Código de Processo Civil Brasileiro e a experiência portuguesa, in Revista de processo, vol. 230, abr/2014, p. 369.
} 
Revista Eletrônica de Direito Processual - REDP. Volume 15. Janeiro a Junho de 2015 Periódico Semestral da Pós-Graduação Stricto Sensu em Direito Processual da UERJ. Patrono: José Carlos Barbosa Moreira. www.redp.com.br ISSN 1982-7636 PP 240-267

também seria recomendável que se buscassem instrumentos de incentivo à cooperação, como solução a curto prazo.

Seria o caso, por exemplo, de se prever "prêmios" que beneficiassem aquele que adotou uma postura cooperativa durante o processo, ao invés de punir aquele que não cooperou.

Embora a questão seja nova e mereça maior amadurecimento, poderíamos supor que, diante da discricionariedade concedida pelo texto do novo CPC ao magistrado, este poderia premiar a parte que demonstrasse, de forma inquestionável, conduta colaborativa.

Perceba-se que não se trata, apenas, de agir com boa fé. É bem mais do que isso. Agir com boa fé significa se abster de incidir em alguma das condutas tipificadas como atos de improbidade processual. Agir de forma colaborativa significa uma conduta próativa. É um fazer quando o agente poderia, simplesmente, se omitir. É esse plus que merece ser premiado.

Obviamente, seria interessante que o próprio texto legal trouxesse parâmetros ou hipóteses autorizadoras.

Apenas para dar um exemplo, em termos de mediação, a Comissão do Ministério da Justiça, que preparou o Projeto de Lei do Senado ${ }^{\circ} 434 / 14$, hoje anexado aos demais Projetos e submetido à Câmara, sob o número PL 7.169/14, sugeriu que o magistrado pudesse reduzir as custas até a metade em favor da parte que demonstrasse, no curso do processo, ter envidados esforços no sentido de buscar o acordo, quer seja pela via da conciliação ou da mediação.

Ou seja, ao invés de sancionar a parte que se recusa a buscar o acordo, premia-se aquele que se mostra mais receptivo e de fato se engaja nessa empreitada.

Voltando ao cenário norte-americano, infelizmente, o comitê encarregado das alterações nas Federal Rules of Civil Procedure se manteve distante da discussão mais aprofundada sobre o escopo e consequências da implementação da cooperação no processo civil, limitando-se a afastar de pronto uma possível interpretação que autorizasse a aplicação de sanções punitivas com base nela ou que limitasse outras regras processuais.

No mesmo sentido, o relatório da Judicial Conference reconhece que a emenda da regra 1, por si só, "não irá produzir comportamento razoável e cooperativo entre os litigantes", mas afirma acreditar que "a emenda proposta irá proporcionar um passo 
Revista Eletrônica de Direito Processual - REDP. Volume 15. Janeiro a Junho de 2015

Periódico Semestral da Pós-Graduação Stricto Sensu em Direito Processual da UERJ.

Patrono: José Carlos Barbosa Moreira. www.redp.com.br ISSN 1982-7636 PP 240-267

significativo nessa direção”, ressaltando que essa “mudança deve ser combinada com esforços para educar os litigantes e as Cortes da importância da cooperação na redução de custos desnecessários no processo civil" ${ }^{\text {"19. }}$.

\section{A cooperação no novo Código de Processo Civil Brasileiro}

Em diversos outros ordenamentos jurídicos, além do norte-americano, a cooperação já é uma realidade.

A doutrina costuma apontar a origem da cooperação no Direito Alemão. Com efeito, é possível identificar na ZPO alemã diversos dispositivos que consagram, através de regras específicas, um modelo de processo cooperativo ${ }^{20}$. Tais dispositivos trazem não somente previsões de deveres para o juiz, como também para as partes, as quais tem o dever de atuar na gestão adequada do processo dentro de uma "comunidade de trabalho" com o juiz e com o seu adversário ${ }^{21}$.

No que tange aos deveres do magistrado, diversos dispositivos poderiam ser mencionados. A título exemplificativo, cita-se o $§ 139$ da ZPO, que incorpora o denominado dever de indicação (Hinweispflicht), consistente no dever do órgão judicial de provocar as partes para discutirem as questões de fato e de direito, de modo a deixar claras as suas linhas de argumentação.

Posterior reforma da ZPO tratou de reforçar ainda mais este dever, passando a prever no $\$ 139$ que "em princípio é vedado ao tribunal colocar-se, para fundamentar sua decisão, em ponto de vista estranho ao das partes, por elas considerado irrelevante ou por ambos valorado de maneira diferente da que parece correta ao órgão judicial, a menos que este lhes faça a respectiva indicação e lhes dê ensejo de manifestar-se "22.

Na mesma linha do Direito Alemão, mas dando um passo além, o Direito Português traz em seu código de processo civil a previsão expressa de uma cláusula geral da cooperação, ao estabelecer que " $[n]$ a condução e intervenção no processo,

\footnotetext{
19 "The Committee recognizes that a rule amendment alone will not produce reasonable and cooperative behavior among litigants, but believes that the proposed amendment will provide a meaningful step in that direction. This change should be combined with continuing efforts to educate litigants and courts on the importance of cooperation in reducing unnecessary costs in civil litigation". (tradução livre)

${ }^{20}$ GROSS, Marco Eugênio. A colaboração processual como produto do Estado Constitucional e as suas relações com a segurança jurídica, a verdade e a motivação da sentença, in Revista de Processo, vol. 226, Dez/2013, p. 115.

${ }^{21}$ GREGER, Reinhard. Cooperação como princípio processual. Tradução Ronaldo Kochem. Revista de Processo, v. 206, p. 123, abr. 2012. Título original: Kooperation als Prozessmaxime.

${ }^{22}$ MOREIRA, José Carlos Barbosa. Breve notícia sobre a reforma do processo civil alemão. Temas de direito processual $-8^{a}$ série. São Paulo: Saraiva, 2004, p. 201-202.
} 
Revista Eletrônica de Direito Processual - REDP. Volume 15. Janeiro a Junho de 2015 Periódico Semestral da Pós-Graduação Stricto Sensu em Direito Processual da UERJ. Patrono: José Carlos Barbosa Moreira. www.redp.com.br ISSN 1982-7636 PP 240-267

devem os magistrados, os mandatários judiciais e as próprias partes cooperar entre si, concorrendo para se obter, com brevidade e eficácia, a justa composição do litígio”.

Esta norma, que estava no art. $266, \S 1^{\circ}$, do antigo Código ${ }^{23}$, foi mantida no novo Código processual português, aprovado em 2013, mas agora em nova localização: no título referente aos princípios fundamentais do processo civil, no art. $7^{\circ}$, I.

A maioria da doutrina portuguesa entende que o princípio da cooperação, consagrado nesse dispositivo legal, demanda a sua concretização por meio de regras específicas, não sendo dotado, portanto, segundo essa concepção, de eficácia normativa direta.

Em sentido contrário, Fredie Didier aponta que, independentemente de previsão normativa expressa de regras específicas que concretizem o seu comando, o princípio da cooperação pode ser aplicado de forma direta para exigir de todos os sujeitos processuais (i.e. partes e magistrados) uma atuação cooperativa e proporcional aos fins do processo. Com base nisso, conclui o autor pela possibilidade de se "cogitar de situações jurídicas processuais atípicas decorrentes da eficácia direta com função integrativa do princípio da cooperação" 24 .

De forma semelhante ao que foi feito recentemente em Portugal, o novo Código de Processo Civil brasileiro, ao menos em sua versão atual, ainda pendente de sanção presidencial, também traz um título e um capítulo dedicados às normas fundamentais do processo civil, dentre as quais se destaca a previsão expressa de uma cláusula geral de cooperação.

\footnotetext{
${ }^{23}$ Comentando o art. 266.o do CPC português (antigo), anota António Santos Abrantes Geraldes que o dever de colaboração no processo vai além das partes e do juiz. Segundo o autor português: "O 'princípio da cooperação', previsto no art. 166o, deve orientar os comportamentos processuais dos magistrados, dos mandatários das partes, mas, por maioria de razão, deve servir de comportamento dos 'funcionários de justiça', sem o que de pouco valerá a enunciação daquela norma programática. Se até as 'pessoas que não são parte na causa' estão sujeitas ao dever de cooperação, como resulta do art. 519.o, é bom de ver que o exemplo deve ser dado por quem, no tribunal, exerce funções intermediárias entre o juiz e os cidadãos ou os advogados. $O$ art. 161.o, $n$. 1, que prevê a 'dependência funcional' da secretaria relativamente ao magistrado competente, configurar-se-ia como uma norma plenamente dispensável se não fosse o objetivo de evitar absurdos atritos no relacionamento entre os funcionários e os magistrados. Mas de tal preceito resulta claramente que devem as secretarias assegurar o expediente e regular tramitação dos processos pendentes, constituindo, aliás, um pressuposto básico para que, através dos processos judiciais, se possa obter a justa composição do litígio, prevista no art. 266.o, $n$. 1, e alcançar uma decisão célere que satisfaça os interesses das partes e da administração da justiça. Por conseguinte, e para que não haja quaisquer equívocos, a secretaria constitui um instrumento necessário para a litigância de má-fé (sanção pecuniária). boa administração da justiça, sob a 'superior orientação do juiz do processo', aquele que, em última análise, responde pelo bom ou mau funcionamento dos serviços judiciais". GERALDES, António Santos Abrantes. Temas da reforma do processo civil. Coimbra: Almedina, 1997, p. 78.

${ }^{24}$ DIDIER JR., Fredie. Fundamentos do Princípio da Cooperação no Direito Processual Civil Português. Coimbra: Coimbra Editora, 2010, p. 52.
} 
Revista Eletrônica de Direito Processual - REDP. Volume 15. Janeiro a Junho de 2015 Periódico Semestral da Pós-Graduação Stricto Sensu em Direito Processual da UERJ. Patrono: José Carlos Barbosa Moreira. www.redp.com.br ISSN 1982-7636 PP 240-267

É verdade, por outro lado, que o NCPC também traz, na linha do Direito Alemão, a previsão de diversas normas específicas que incorporam o espírito cooperativo no processo civil de forma mais concreta, sempre com o objetivo de conferir mais celeridade e eficácia ao exercício da jurisdição. Assim, por exemplo, o art. 10 do novo Código prevê que o Juiz, antes de proferir qualquer decisão, mesmo sobre questões que ele pode conhecer de ofício, deve dar às partes a oportunidade de se manifestarem sobre a matéria.

Este dispositivo consagra o dever de consulta, um dos deveres do juiz derivados do princípio da cooperação, que assegura, também a observância do contraditório participativo, na medida em que tem como contrapartida o direito de participação das $\operatorname{partes}^{25}$.

Contudo, não obstante a importância dessas regras específicas, a grande novidade trazida pelo NCPC continua sendo a cláusula geral da cooperação, a partir da qual, de acordo com aquela concepção de Fredie Didier Jr., poderão ser extraídas situações jurídicas atípicas.

Antes de se chegar a qualquer conclusão, contudo, sobre os efeitos e consequências da implementação da cooperação, há que se investigar o escopo e o conteúdo desta norma-princípio.

A cooperação vem prevista no art. $6^{\circ}$ do novo Código, inserto no capítulo "Das Normas Fundamentais do Processo Civil”, e que estabelece que "[t]odos os sujeitos do processo devem cooperar entre si para que se obtenha, em tempo razoável, decisão de mérito justa e efetiva".

A primeira questão que se coloca é: qual o fundamento constitucional para a cooperação? Seria constitucional a previsão de um dever de cooperação das partes “entre si”? Alguns autores entendem que não.

Em texto com viés crítico ${ }^{26}$, Lenio Streck, Lúcio Delfino, Rafael Barba e Ziel Lopes, afirmaram que a cooperação processual, tal como prevista no novo CPC, é "algo que não se encaixa bem como que diz a Constituição e sua principiologia”.

\footnotetext{
${ }^{25}$ RAATZ, Igor. Colaboração no processo civil e o projeto do novo código de processo civil. Revista da SJRJ, Rio de Janeiro, v. 18, n. 31, p. 23-36, ago 2011. Disponível em: <http://www4.jfrj.jus.br/seer/index.php/revista_sjrj/article/view/274>. Acessado em: 17 jul. 2013.

${ }^{26}$ STRECK, Lenio; DELFINO, Lúcio; BARBA, Rafael Giorgio Dalla; LOPES, Ziel Ferreira. Aposta na bondade - a cooperação processual do novo CPC é incompatível com a Constituição. Consultor Jurídico, 23 de dezembro de 2014. Disponível em: <http://www.conjur.com.br/2014-dez-23/cooperacaoprocessual-cpc-incompativel-constituicao>. Acesso em 26 jan 2015.
} 
Revista Eletrônica de Direito Processual - REDP. Volume 15. Janeiro a Junho de 2015 Periódico Semestral da Pós-Graduação Stricto Sensu em Direito Processual da UERJ. Patrono: José Carlos Barbosa Moreira. www.redp.com.br ISSN 1982-7636 PP 240-267

A razão para essa assertiva se baseia, primeiramente, em um entendimento dos autores de que a cooperação não poderia ser considerada um princípio per se. Esse entendimento já havia sido exposto por Lenio Streck no passado em artigo para a Revista de Processo, no qual afirmava que a cooperação não seria dotada de suficiente normatividade para poder ser considerada um princípio. Nesse sentido, o autor suscitava as seguintes questões: "e se as partes não cooperarem? Em que condições um standard desse quilate pode efetivamente ser aplicado? Há sanções no caso de não cooperação? Qual será a ilegalidade ou inconstitucionalidade decorrente da sua não aplicação?"”27.

No artigo recentemente publicado no site Consultor Jurídico em colaboração com Lúcio Delfino, Rafael Barba e Ziel Lopes, Lenio Streck vai além: além de não ser um princípio, a cooperação processual sequer estaria de acordo com os princípios constitucionais. A conclusão parte de, basicamente, duas premissas. Em primeiro lugar, afirma-se que não seria possível imputar deveres para as partes com base no princípio do contraditório, tido como "matriz basilar" para a cooperação, mas apenas para o magistrado.

Assim, o art. $6^{\circ}$ do novo CPC, ao atribuir as partes o dever de obtenção de decisão de mérito justa, efetiva e em tempo razoável, estaria violando uma determinação constitucional de que este dever cabe única e exclusivamente ao Estado.

Em segundo lugar, e esta parece ser a grande preocupação dos autores no artigo, está a possibilidade de a cooperação processual dar azo à discricionariedade dos magistrados e à limitação de direitos e garantias processuais individuais.

Assim, em vista dessas premissas, os autores propõem ao final da sua análise que seja feita uma interpretação conforme do art. $6^{\circ}$ do novo CPC para lê-lo da seguinte forma: "o juiz deve cooperar com as partes para que se obtenha, tem tempo razoável, decisão de mérito, justa e efetiva”.

Não obstante a perspectiva interessante sobre a questão da cooperação no processo civil trazida pelo texto, não podemos endossar as suas premissas, nem as suas conclusões.

É certo que, especialmente nesse momento inicial, há mais perguntas do que respostas para a implementação da cooperação processual. Isso não significa, todavia, que devamos, de forma prematura, considerar que ela esteja fadada ao fracasso, em

27 STRECK, Lenio. Um debate com (e sobre) o formalismo-valorativo de Daniel Mitidiero, ou “colaboração no processo civil” é um princípio? Revista de Processo. Vol. 213/2012, nov. 2012., p. 17. 
Revista Eletrônica de Direito Processual - REDP. Volume 15. Janeiro a Junho de 2015 Periódico Semestral da Pós-Graduação Stricto Sensu em Direito Processual da UERJ. Patrono: José Carlos Barbosa Moreira. www.redp.com.br ISSN 1982-7636 PP 240-267

razão de uma suposta "impossibilidade natural" do homem em cooperar no âmbito de um litígio, ou que ela traga, de forma inerente, uma propensão para o arbítrio dos magistrados na sua aplicação.

Consequentemente, não devemos limitar o seu escopo. Excluir da cooperação o dever de as partes cooperarem entre si seria tornar inócua uma das suas principais finalidades, qual seja, de tornar o processo civil algo mais eficaz, mais célere e menos custoso.

Quando aplicada aos magistrados a cooperação gera uma série de deveres ${ }^{28}$, que visam, em suma, aperfeiçoar a prestação jurisdicional e garantir a prolação de decisões mais justas. Com relação às partes, a cooperação também é apta a gerar deveres que têm como objetivo incentivar uma atuação mais ética e escorreita, e, com isso, colaborar para a entrega da prestação jurisdicional em tempo razoável e com menor custo.

A experiência mostrou que, sem a cooperação das partes, não há como promover a celeridade do processo judicial. A existência no processo civil brasileiro de inúmeros instrumentos e recursos à disposição das partes para assegurar os direitos e garantias constitucionais processuais demanda uma atuação cooperativa das partes e de seus procuradores que atente para as necessidades do caso concreto, para o uso adequado dos instrumentos processuais e para as limitações do Poder Judiciário, já assoberbado de processos.

O texto em exame passa a impressão de ter levado em consideração apenas os deveres decorrentes da cooperação que são direcionados às partes, deixando de lado a parte do princípio que se dirige ao magistrado. Com efeito, é importante lembrar que o art. $6^{\circ}$ do novo CPC não fala apenas que as partes devem cooperar entre si, mas sim que todos os sujeitos processuais devem cooperar entre eles.

Dessa forma, é um equívoco pensar que a cooperação vai dar uma carta branca para que o juiz aja da forma que bem entender, aplicando sanções indiscriminadamente e limitando direitos e garantias constitucionais.

A liberdade das partes no processo continuará existindo, mas ela não poderá ser exercida em desatenção às regras do processo. Por outro lado, não se está impondo, através do princípio da cooperação, um “comportamento absolutamente altruísta dos

\footnotetext{
${ }^{28}$ São eles: dever de esclarecimento, dever de prevenção, dever de consulta e dever de auxílio. Para mais informações, v. PINHO, Humberto Dalla Bernardina de; ALVES, Tatiana Machado. A cooperação e a principiologia no processo civil brasileiro. Uma proposta de sistematização. Revista Eletrônica de Direito Processual, v. 12, disponível em www.redp.com.br.
} 
Revista Eletrônica de Direito Processual - REDP. Volume 15. Janeiro a Junho de 2015 Periódico Semestral da Pós-Graduação Stricto Sensu em Direito Processual da UERJ. Patrono: José Carlos Barbosa Moreira. www.redp.com.br ISSN 1982-7636 PP 240-267 litigantes adversários no desenrolar do feito”, o que seria completamente utópico e irrealizável. Autor e réu têm, evidentemente, interesses parciais e contrapostos no processo.

O que se busca, de fato, quando se defende que as partes - além do magistrado devem cooperar entre si, é uma atuação ética e correta dos indivíduos na exposição dos fatos, na defesa dos seus direitos e na identificação das questões que realmente reclamam a intervenção judicial, colaborando com o juiz para que mérito seja resolvido de forma justa e em tempo razoável.

Dentro dessa perspectiva, fica claro que a cooperação está em plena consonância com a Constituição Federal de 1988. Até mesmo porque dizer que ela se pauta apenas no contraditório é desconsiderar os matizes que a cooperação possui ${ }^{29}$.

O contraditório é um fundamento da cooperação principalmente quando consideramos a cooperação enquanto geradora de deveres para o magistrado, na medida em que o contraditório representa um direito da parte de "influência na construção dos provimentos jurisdicionais", assegurando a efetiva participação de todos os sujeitos processuais e impondo sobre o juiz o dever de observar essa determinação.

Num contraponto, o contraditório deve ser visto como um direito das partes que deve ser exercido dentro de certos limites, dentre os quais o dever das partes de cooperaram e colaborarem para a resolução da lide no menor tempo possível (i.e. razoável) e com o menor custo, assegurando a efetividade da prestação jurisdicional e a justiça das decisões judiciais. Isso porque não se pode esquecer o interesse público imanente ao processo e na administração da Justiça, afetada pela conduta das partes ${ }^{30}$.

Dessa forma, se por um lado o contraditório visa garantir a possibilidade de manifestação e influência das partes na formação das decisões judiciais, por outro lado, tal participação deve ser ética e colaborativa.

Outrossim, ressalta Fabio Milman que não é possível extrair, a partir do direito ao contraditório e à ampla defesa, uma autorização para o exercício ilimitado do processo, tendo em vista a inegável existência de "regras de conduta, dentro do

\footnotetext{
29 De fato, colaboração processual encontra as suas raízes no Estado Constitucional. Como bem salientado por Marco Eugênio Gross ${ }^{29}$, ela deriva de dois núcleos estatais: (a) do Estado de Direito, sobretudo a partir da ideia de segurança jurídica; e (b) do Estado Democrático, a partir da ideia de participação (já que a participação constitui a base constitucional para a colaboração no processo).

30 MITIDIERO, Daniel. A Colaboração como modelo e como Princípio no processo civil, in https://www.academia.edu/10250562/Coopera\%C3\%A7\%C3\%A3o_como_Modelo_e_como_Princ\%C3 \%ADpio_no_Processo_Civil, acesso em 05 de fevereiro de 2014.
} 
Revista Eletrônica de Direito Processual - REDP. Volume 15. Janeiro a Junho de 2015 Periódico Semestral da Pós-Graduação Stricto Sensu em Direito Processual da UERJ. Patrono: José Carlos Barbosa Moreira. www.redp.com.br ISSN 1982-7636 PP 240-267 exercício das mencionadas prerrogativas" 31 que regulam a atuação das partes no processo.

Dessa forma, é perfeitamente possível e aceitável que o contraditório seja entendido como fonte de deveres os quais, de certa formam, adequam mesmo a sua aplicação como direito.

Nessa dimensão, a cooperação, além de ser a base para deveres típicos e atípicos, orienta, enquanto princípio, a interpretação e aplicação de normas que tem como objetivo assegurar não só a observância do contraditório pelo magistrado, mas também pelas partes.

Ainda que assim não o fosse, se o contraditório não pudesse ser considerado um fundamento constitucional para o aspecto da cooperação das partes entre si, isso não significa que a cooperação neste sentido é inconstitucional.

Pode-se apontar, por exemplo, como outro fundamento constitucional para a cooperação, o princípio da solidariedade, inscrito no inciso I do artigo $3^{\circ}$ da Constituição Federal de $1988^{32}$, o qual, ao estabelecer como objetivo fundamental da República Federativa do Brasil a construção de uma "sociedade livre, justa e solidária”, estaria instituindo um "dever fundamental de solidariedade, do qual decorreria o dever de não quebrar a confiança e de não agir com deslealdade",33.

A priori, parece que não há muita compatibilidade entre solidariedade e processo. Mas talvez isso derive de uma concepção errônea de processo que a comunidade jurídica no geral nutre atualmente. Enquanto continuarmos considerando o processo como uma arena de batalhas, na qual vale tudo para se sagrar o vencedor, de fato não haverá muito espaço para solidariedade.

Contudo, essa concepção é extremamente prejudicial não só para o processo como para a sociedade como um todo, pois gera um sentimento coletivo de que qualquer problema que surge, por menor que ele seja, somente será resolvido na esfera judicial - e por uma decisão imposta de cima para baixo pelo juiz.

A cooperação surge, portanto, como uma forma de auxiliar a concretizar no processo civil essa solidariedade preconizada pela Constituição.

\footnotetext{
${ }^{31}$ MILMAN, Fabio. Improbidade processual. 2. ed. Rio de Janeiro: Forense, 2009, p. 84.

${ }^{32}$ VINCENZI, Brunela Vieira de. A boa-fé no processo civil. São Paulo: Atlas, 2003, p. 163.

${ }^{33}$ DIDIER JR., Fredie. Op. cit., p. 86
} 
Revista Eletrônica de Direito Processual - REDP. Volume 15. Janeiro a Junho de 2015

Periódico Semestral da Pós-Graduação Stricto Sensu em Direito Processual da UERJ.

Patrono: José Carlos Barbosa Moreira. www.redp.com.br ISSN 1982-7636 PP 240-267

A solidariedade se correlaciona diretamente com a fraternidade do direito, preconizada pelo jurista italiano Eligio Resta ${ }^{34}$.

Em artigo sobre o tema, Marco Aurélio Marrafon denuncia a falência do modelo de direito atual ${ }^{35}$, de base extremamente individualista, que se preocupa muito pouco com o próximo, em prol de um modelo de direito fraterno, não violento, no qual as relações jurídicas se pautam em uma "maior simetria $e[\mathrm{na}]$ responsabilidade recíproca pelos nossos atos e pela guarda primária do direito do próximo, enquanto expressão maior da fraternidade" 36 .

Destarte, não há dúvidas que o princípio da cooperação representa um avanço importante rumo à incorporação da fraternidade no Direito, especialmente no Direito Processual, que parece mais esgotado em razão da beligerância dos sujeitos ${ }^{37}$.

Todavia, não se pode ignorar os desafios concretos que a implementação da cooperação apresenta: o que acontece se uma ou ambas as partes não cooperarem? Qual o núcleo essencial (já que estamos falando de princípio) da cooperação? Quais os parâmetros que permitem auferir se houve ou não cooperação? Como esse princípio seria aplicado na prática?

\section{Os desafios para a implementação da cooperação no processo}

A construção do conteúdo do conceito de cooperação dependerá da praxe judiciária e de uma atuação ativa da doutrina brasileira. Se nem nos ordenamentos jurídicos nos quais a discussão já está em estágio mais avançado há um consenso sobre os limites, efeitos e conteúdo da cooperação, não podemos esperar que a resposta para todas aquelas perguntas caia do céu.

\footnotetext{
${ }^{34}$ RESTA, Eligio (trad. Sandra Vial). O Direito Fraterno. Santa Cruz do Sul: EDUNISC, 2004.

35 De forma precisa, Marco Aurélio Marrafon aponta que “[p]assados alguns séculos desde as grandes revoluções jurídicas da modernidade, o esfacelamento ético-moral da sociedade (quanto menos prevalece a ética social, mais o direito se torna necessário para estabilizar as relações e condutas humanas), a intolerância oriunda dos maniqueísmos e o excessivo apego ao judiciário como superego da sociedade (afinal não conseguimos resolver pacificamente nem a guarda do nosso animal de estimação, tendo que recorrer ao juiz para que ele estabeleça a guarda cão-partilhada, como tem se tornado comum nas ações de divórcio) são sintomas evidentes de esgotamento do atual modelo". (in O futuro do Direito como Direito fraterno. Consultor Jurídico, 29 de dezembro de 2014. Disponível em $<$ http://www.conjur.com.br/2014-dez-29/constituicao-poder-futuro-direito-direito-fraterno $>$. Acesso em 26 jan. 2015.).

${ }^{36}$ MARRAFON, Marco Aurélio. O futuro do Direito como Direito fraterno. Consultor Jurídico, 29 de dezembro de 2014. <http://www.conjur.com.br/2014-dez-29/constituicao-poder-futuro-direito-direitofraterno>. Acesso em 26 jan. 2015.

37 SPENGLER, Fabiana Marion; SPENGLER NETTO, Theobaldo. A boa-fé e a cooperação previstas no PL 8.046/2010 (Novo CPC) como princípios viabilizadores de um tratamento adequado dos conflitos judiciais, in Revista de Processo, vol. 230, abr/2014, p. 13.
} 
Revista Eletrônica de Direito Processual - REDP. Volume 15. Janeiro a Junho de 2015 Periódico Semestral da Pós-Graduação Stricto Sensu em Direito Processual da UERJ. Patrono: José Carlos Barbosa Moreira. www.redp.com.br ISSN 1982-7636 PP 240-267

O potencial amadurecimento da discussão no Brasil em virtude da previsão da cláusula geral da cooperação no novo Código de Processo Civil poderá, inclusive, colocar o Brasil na vanguarda da construção do conteúdo e da aplicação prática da cooperação.

No Estados Unidos, a cooperação é usada muitas vezes com um norte para o juiz na direção do processo e na interpretação da conduta das partes, auxiliando na formação de seu convencimento sobre determinadas questões.

No caso Kleen Products LLC, et al., v. Packaging Corporation of America, et $a l .{ }^{38}$, por exemplo, no qual se discutiam supostas práticas antitrustes da indústria de papelão, o Juiz Nan R. Nolan buscou promover a cooperação entre as partes para alcançar consenso em questões atinentes à produção de provas.

$\mathrm{Na}$ fundamentação de decisão de 28 de setembro de 2012 ("memorandum opinion"), o magistrado afirma que "graças ao trabalho duro dos advogados, as partes e a Corte puderam resolver uma série de questões através de reuniões deliberativas", descrevendo, em seguida, os diversos pontos comuns que as partes, através de seus procuradores, conseguiram encontrar.

Quando não foi possível às partes chegarem, sempre com o auxílio neutro do magistrado, a um consenso através da cooperação, esta serviu como parâmetro para que o Juiz pudesse decidir as questões sobre as quais ainda havia disputa.

Uma dessas questões, por exemplo, dizia respeito ao pedido dos autores para produção de provas suplementares. Ocorre que havia sido solicitado a uma das empresas-rés que ela fornecesse informações a respeito dos funcionários envolvidos na comercialização de papelão.

Tal empresa, embora afirmasse não manter um organograma ou descrições formais das funções de seus empregados, concordou, em vista da cooperação, fazer uma lista com o nome e os títulos dos indivíduos que teriam relação com o litígio. Três dias após o fornecimento desta lista, os autores formularam um requerimento para produção de provas suplementares, consistentes no fornecimento de várias informações complexas sobre os últimos 8 anos de empresa de aproximadamente 400 pessoas daquela lista.

\footnotetext{
${ }^{38}$ Disponível em: $<$ http://blog.millnet.co.uk/resources/Kleen_Products_v._Packaging_Corp.pdf $>$. Acesso em 10 fev. 2015.
} 
Revista Eletrônica de Direito Processual - REDP. Volume 15. Janeiro a Junho de 2015 Periódico Semestral da Pós-Graduação Stricto Sensu em Direito Processual da UERJ. Patrono: José Carlos Barbosa Moreira. www.redp.com.br ISSN 1982-7636 PP 240-267

A empresa-ré requereu, então, à Corte uma medida protetiva, alegando que 0 pedido dos autores era injusto e lhe causaria um dano desproporcional, além de não trazer nenhum benefício prático para o processo.

Em sua decisão o Juiz levou em consideração, além dos requisitos regulares para o deferimento ou não dessa espécie de medida, a observância do "espírito de cooperação" pelas partes. No caso concreto, ele entendeu que a apresentação da lista pela empresa-ré foi feita imbuída do espírito cooperativo, com vistas a auxiliar as autoras na sua própria reconstrução dos fatos, em conjunto com os demais documentos que já haviam sido fornecidos pela empresa-ré.

Assim, ao requerer a produção de prova suplementar, ainda mais tão poucos dias após a apresentação da lista, as autoras estariam violando o espírito de cooperação. Tal conduta poderia ainda, segundo o juiz, esfriar a disposição dos litigantes e da Corte em se engajar em discussões amigáveis.

Outro ponto interessante é que a lista em questão havia sido inicialmente fornecida pela empresa-ré após uma reunião entre as partes e o juiz na qual este, "atuando como um neutro, facilitou um debate informal com as partes" e sugeriu a hipótese da lista. Este exemplo demonstra perfeitamente que o estabelecimento de uma comunidade de trabalho entre os sujeitos do processo para alcançar a melhor solução para todos está longe de ser uma utopia, ou de representar uma violação ao dever de imparcialidade do magistrado.

Diante disso, uma vez que a prova suplementar requerida violava o teste de proporcionalidade, por trazer mais ônus do que benefícios, e o espírito de cooperação, o juiz norte-americano decidiu deferir a medida protetiva requerida pela ré, impedindo assim a realização da prova.

A decisão do Juiz Nan R. Nolan deve ser aplaudida pelo esforço empreendido em promover a cooperação no processo e educar as partes e os advogados para, aos poucos, se adaptarem a este novo modo de litigar.

Conforme muito bem ressaltado pelo magistrado na conclusão de sua fundamentação, "[n] a busca de uma abordagem colaborativa, algumas lições devem ser aprendidas", sendo a primeira, e talvez a principal delas, a de que esta abordagem deve começar no início do processo, sob pena de gerar um vício de disputa nas partes que é difícil de ser desfeito depois. 
Revista Eletrônica de Direito Processual - REDP. Volume 15. Janeiro a Junho de 2015 Periódico Semestral da Pós-Graduação Stricto Sensu em Direito Processual da UERJ. Patrono: José Carlos Barbosa Moreira. www.redp.com.br ISSN 1982-7636 PP 240-267

Ao menos parte da atuação do juiz norte-americano no caso em comento pode ser transplantada para a realidade brasileira sob a égide do Novo CPC, uma vez que este diploma trará em seu art. 357 , parágrafos $1^{\circ}, 2^{\circ}$ e $3^{\circ}$, importante previsão que busca promover a cooperação e a participação das partes no saneamento do feito, atuando em colaboração com o magistrado.

O parágrafo $1^{\mathrm{o}}$ do referido dispositivo prevê o direito de influência das partes, importante consectário do princípio da cooperação, no saneamento do processo, conferindo a elas o direito de "pedir esclarecimentos ou solicitar ajustes, no prazo comum de cinco dias, findo o qual a decisão se torna estável”.

Por sua vez, o parágrafo $2^{\circ}$ confere às partes a possibilidade de delimitarem consensualmente as questões de fato sobre as quais recairá a atividade probatória e as questões de direito relevantes para a decisão de mérito. Homologada pelo juiz, essa delimitação será vinculante para as partes e para o juiz. Com esse dispositivo, o NCPC confere às partes um importante papel na direção do processo, sempre, evidentemente, subordinadas à verificação pelo juiz da regularidade no exercício desse direito, que não pode servir como um instrumento de opressão da parte mais forte.

Já o parágrafo $3^{\circ}$, seguindo uma linha que, conforme visto, já é adotada no direito norte-americano, prevê a realização de "audiência de saneamento" quando a causa for complexa. Este é, provavelmente, um dos dispositivos do NCPC que melhor exemplifica a concretização da cooperação no processo civil. Através dessas "audiências de saneamento", que, de acordo com a própria previsão legal, devem ser realizadas em cooperação, será possível estabelecer um canal mais aberto de comunicação entre as partes e o magistrado, de forma que todos possam efetivamente inferir na formação do despacho saneador e na condução do processo, minimizando as chances de insatisfação das partes e eliminado o risco de prolação de "decisõessurpresa".

Em outro caso norte-americano - E.I. DuPont de Nemours and Company v. Kolon Industries, Inc ${ }^{39}$. - a condução do feito pelo juiz fornece relevantes elementos para a aplicação da cooperação. Neste caso, embora a cooperação não tenha sido aplicada diretamente, a conduta das partes foi adotada pelo Juiz Robert E. Payne como

\footnotetext{
39 Disponível em: < http://www.ca4.uscourts.gov/Opinions/Unpublished/121260.U.pdf>. Acesso em 10
} fev. 2015 
Revista Eletrônica de Direito Processual - REDP. Volume 15. Janeiro a Junho de 2015 Periódico Semestral da Pós-Graduação Stricto Sensu em Direito Processual da UERJ. Patrono: José Carlos Barbosa Moreira. www.redp.com.br ISSN 1982-7636 PP 240-267 um dos parâmetros para decidir, em 2012, sobre a condenação da parte vencida (Kolon Industries) ao pagamento de attorneys fees.

Com base nos critérios estabelecidos pelo Court of Appeals for the Federal Circuit no caso Delta-X Corp. v. Baker Hughes Production Tools, Inc., o juiz do caso DuPont v. Kolon buscou verificar se seria possível imputar ao vencido a culpa pelo ônus causado pelo litígio. Um dos aspectos observados foram as táticas empregadas pelas partes e seus advogados durante o procedimento.

No caso, o juiz entendeu que embora algumas táticas empregadas pelos advogados da Kolon tenham sido normais deste tipo de disputa, estando de acordo, portanto, com os mandamentos da advocacia zelosa, outras manobras adotadas foram agressivas e desnecessárias. Como exemplo é citada a postura da Kolon em demorar excessivamente para fornecer documentos cuja apresentação tinha sido determinada pelo magistrado, atrasando intencionalmente o procedimento.

Muito embora esta decisão não fale expressamente em cooperação, a conduta da Kolon denota a ausência de compromisso desta com uma atuação cooperativa, voltada para a resolução da lide da forma mais eficiente possível e em menor tempo. A repúdia do magistrado a este comportamento é indicativa da influência ainda que indireta que a cooperação exerce sobre as decisões do magistrado, enquanto um reflexo do clamor deste por uma disputa mais justa, limpa e cordial entre as partes.

\section{Conclusão}

Enquanto o processo continuar sendo visto como uma arena de batalhas entre as partes, ele ficará muito longe de alcançar sua finalidade de promover a pacificação social, a qual se concretiza não somente com a prolação de uma decisão que vem de cima para baixo, imposta por um juiz Hércules, mas com a verdadeira composição dos interesses contrapostos em jogo.

De nada adianta resolver a querela entre as partes se elas sairão do processo se odiando e insatisfeitas com o resultado da prestação jurisdicional - especialmente com os gastos de tempo e de dinheiro incorridos para chegar ao final do processo.

A adoção de uma postura beligerante não é sinônimo de advocacia zelosa. Outrossim, tampouco está de acordo com os direitos e garantias processuais constitucionais, uma vez que ela afeta a própria eficácia do exercício da jurisdição e do 
Revista Eletrônica de Direito Processual - REDP. Volume 15. Janeiro a Junho de 2015 Periódico Semestral da Pós-Graduação Stricto Sensu em Direito Processual da UERJ. Patrono: José Carlos Barbosa Moreira. www.redp.com.br ISSN 1982-7636 PP 240-267

acesso à Justiça, tornando o processo algo mais longo e custoso, e contribuindo para atravancar o Poder Judiciário com milhares de ações que nunca terminam.

Se a disputa é algo inerente às sociedades complexas, e que decorre das inúmeras diferenças entre as pessoas, também a cooperação é um pressuposto essencial da construção e do desenvolvimento da vida social. Mais soluções são alcançadas através do diálogo do que através de brigas.

Nesse sentido, é importante que o processo seja visto como o mecanismo legal, estatal, oficial que ele é, e que se reconheça que ele possui regras, as quais devem ser sempre observadas, de modo que aqueles que tiverem interesse em buscar o Poder Judiciário para resolver suas disputas devem agir de forma responsável e ética.

O caminho a ser trilhado para que a sociedade contemporânea alcance o ideal de um processo mais fraterno e que atenda, com maior eficiência, os direitos e garantias processuais, é longo e árduo. As discussões se espalham por todos os ordenamentos jurídicos nos quais a preocupação com a efetividade e a celeridade do processo assume papel central.

Assim, a previsão de um princípio da cooperação desponta como uma alternativa eficaz para promover um modelo de processo civil que seja isonômico entre partes e magistrado durante o seu desenvolvimento e assimétrico no momento da prolação da decisão.

Da mesma forma, a partir desse princípio é possível extrair uma série de deveres derivados para as partes e seus procuradores que os incentive a adotar um modelo de conduta colaborativa, na qual todos atuam em defesa de seus próprios interesses, mas com respeito para os escopos e as regras do processo, e tendo em vista a importância da prolação de uma sentença de mérito que seja justa, efetiva e proferida em tempo razoável, com o menor custo possível para as partes e para o Estado.

Talvez poucas respostas tenham sido efetivamente dadas por este artigo, mas esperamos que a partir da análise de algumas das premissas aqui expostas e da forma como a discussão vem sendo direcionada em outros ordenamentos jurídicos, tal como o norte-americano, seja possível começar a esboçar algumas soluções para os desafios concretos que irão surgir na implementação da cooperação no novo processo civil brasileiro. 
Revista Eletrônica de Direito Processual - REDP. Volume 15. Janeiro a Junho de 2015 Periódico Semestral da Pós-Graduação Stricto Sensu em Direito Processual da UERJ. Patrono: José Carlos Barbosa Moreira. www.redp.com.br ISSN 1982-7636 PP 240-267

\section{REFERÊNCIAS BIBLIOGRÁFICAS}

DIDIER JR., Fredie. Fundamentos do Princípio da Cooperação no Direito Processual Civil Português. Coimbra: Coimbra Editora, 2010, p. 52.

FARIAS, Marcio. A lealdade processual, o Projeto de novo Código de Processo Civil Brasileiro e a experiência portuguesa, in Revista de processo, vol. 230, abr/2014.

GERALDES, António Santos Abrantes. Temas da reforma do processo civil. Coimbra: Almedina, 1997.

GREGER, Reinhard. Cooperação como princípio processual. Tradução Ronaldo Kochem. Revista de Processo, v. 206, p. 123, abr. 2012. Título original: Kooperation als Prozessmaxime.

GROSS, Marco Eugênio. A colaboração processual como produto do Estado Constitucional e as suas relações com a segurança jurídica, a verdade e a motivação da sentença, in Revista de Processo, vol. 226, Dez/2013.

KANE, Mary Kay. Civil Procedure, $7^{\text {th }}$ edition. West: 2013.

MARCUS, Richard. Cooperation and Litigation: Thoughts on the American $\begin{array}{llllll}\text { Experience, } & \text { p. } & 1 . & \text { Disponível } & \text { em: }\end{array}$ http://papers.ssrn.com/sol3/papers.cfm?abstract_id=2330634>. Acesso em 7 jan 2015. MARRAFON, Marco Aurélio. O futuro do Direito como Direito fraterno. Consultor Jurídico, 29 de dezembro de 2014. <http://www.conjur.com.br/2014-dez29/constituicao-poder-futuro-direito-direito-fraterno>. Acesso em 26 jan. 2015.

MILMAN, Fabio. Improbidade processual. 2. ed. Rio de Janeiro: Forense, 2009, p. 84. MITIDIERO, Daniel. A Colaboração como modelo e como Princípio no processo civil, in

https://www.academia.edu/10250562/Coopera\%C3\%A7\%C3\%A3o_como_Modelo_e_c omo_Princ\%C3\%ADpio_no_Processo_Civil, acesso em 05 de fevereiro de 2014.

MOREIRA, José Carlos Barbosa. Breve notícia sobre a reforma do processo civil alemão. Temas de direito processual - $8^{a}$ série. São Paulo: Saraiva, 2004, p. 201-202.

PINHO, Humberto Dalla Bernardina de; ALVES, Tatiana Machado. A cooperação e a principiologia no processo civil brasileiro. Uma proposta de sistematização. Revista Eletrônica de Direito Processual, v. 12, disponível em www.redp.com.br.

RAATZ, Igor. Colaboração no processo civil e o projeto do novo código de processo civil. Revista da SJRJ, Rio de Janeiro, v. 18, n. 31, p. 23-36, ago 2011. Disponível em: 
Revista Eletrônica de Direito Processual - REDP. Volume 15. Janeiro a Junho de 2015 Periódico Semestral da Pós-Graduação Stricto Sensu em Direito Processual da UERJ. Patrono: José Carlos Barbosa Moreira. www.redp.com.br ISSN 1982-7636 PP 240-267

$<$ http://www4.jfrj.jus.br/seer/index.php/revista_sjrj/article/view/274>. Acessado em: 17 jul. 2013.

RESTA, Eligio (trad. Sandra Vial). O Direito Fraterno. Santa Cruz do Sul: EDUNISC, 2004.

SOUZA, Artur César. O Princípio da Cooperação no Projeto do Novo Código de Processo Civil, in Revista de Processo, vol. 225, Nov. 2013, São Paulo: Revista dos Tribunais.

SPENGLER, Fabiana Marion; SPENGLER NETTO, Theobaldo. A boa-fé e a cooperação previstas no PL 8.046/2010 (Novo CPC) como princípios viabilizadores de um tratamento adequado dos conflitos judiciais, in Revista de Processo, vol. 230, $\mathrm{abr} / 2014$.

STRECK, Lenio; DELFINO, Lúcio; BARBA, Rafael Giorgio Dalla; LOPES, Ziel Ferreira. Aposta na bondade - a cooperação processual do novo CPC é incompatível com a Constituição. Consultor Jurídico, 23 de dezembro de 2014. Disponível em: $<$ http://www.conjur.com.br/2014-dez-23/cooperacao-processual-cpc-incompativelconstituicao>. Acesso em 26 jan 2015.

STRECK, Lenio. Um debate com (e sobre) o formalismo-valorativo de Daniel Mitidiero, ou "colaboração no processo civil" é um princípio? Revista de Processo. Vol. 213/2012, nov. 2012., p. 17.

The Sedona Conference Journal, volume 10, suplemento, 2009. Disponível em: https://thesedonaconference.org/cooperation-proclamation. Acesso em 21 jan 2015.

VINCENZI, Brunela Vieira de. A boa-fé no processo civil. São Paulo: Atlas, 2003, p. 163.

WAXSE, David J. Cooperation - what is it and why do it? XVIII Rich. J.L. \& Tech 8 , 2012. Disponível em: http://jolt.richmond.edu/v18i3/article8.pdf. Acesso em 7 jan 2015. 